\title{
PROJECT MANAGEMENT IN BUILDING INDUSTRY MANAGEMENT
}

\author{
M. Nový, J. Nováková, M. Waldhans
}

Received: May 25, 2012

\begin{abstract}
NOVÝ, M., NOVÁKOVÁ, J., WALDHANS, M.: Project management in building industry management. Acta univ. agric. et silvic. Mendel. Brun., 2012, LX, No. 7, pp. 189-198

The article deals with contents of the project management on general level first. It mentions the most widespread project management standards, which have historically developed in global scale, their parts and objectives. Further, it describes position of the building industry in national economy, its specific features distinguishing it from the other industrial production, contents of the building industry management and project management of structures. The importance of the role of project manager is documented by characteristics of construction projects, their course, contents of sub-phases, and individual types of managing activities. Attention is devoted to project planning - determination of realization costs, necessary resources, sequence and time course of individual works. The most frequently used graphic methods of schedule presentation - Gantt chart, network chart and frequency bar chart are applied on examples of constructions. These charts can be focused in time sequence on individual types of resources - workforce, finance, materials, energies, and machinery. In conclusion, necessity to manage the project management procedures is emphasized as a part of skills of a construction engineer in the role of preparation manager or construction project realization manager.
\end{abstract}

building industry management, project management, construction project planning, realization costs, graphic methods of planning

The entry of this country into the European Union has resulted in opening a full access of the Czech companies to the European market. Only competitive companies, the activities of which create profit and which invest it back into development and innovation of their own company, can be successful there. Generally known conditions of business success are the use of modern technologies, increase of quality, reduction of factory costs, reduction of power demands, environmental protection, planning for real, and keeping of the agreed deadlines. The present requires implementation of both small changes and extensive works within short deadlines, with limited costs and resources. Only team work and application of proven procedures of project design and implementation can provide for satisfaction of these requirements. Appropriately used methods of project management are able to meet all of these requirements.
Investment construction has its own undisputable specifics, which always distinguish its projects from the projects in the area of organisation, research, development, culture, etc. Construction is always tied to a certain place. Construction process is relatively long with long-term effect on its surroundings. Its preparation and realization is contributed to by a large number of participants, the activities of whom must be not only ensured but also coordinated as to place and time. It comprises transfer and processing of considerable amount of material. Construction is always a unique thing, at least as to its geographical and time location (Nový, 2005).

In building industry management, in closer definition understood as a process and construction planning and management, is the most appropriate thing to use project management methods in order to ensure the success (accomplishment of the project objectives under specified conditions). 


\section{Project management}

In former building industry practice, the term project used to be used in the meaning of preparation of design and solution plan of the assigned task in both written and graphic form in accordance with applicable legislation and technical standards. The project was therefore understood as complete documentation, according to which the technical and economic level of the design, its realization plan was assessed and according to which the realization as such took place.

Now, the meaning of project is understood according to its Anglo-Saxon conception as the process of planning and management of extensive operations. Project is not mere documentation, it is rather creative process pursuing the specific target with expected benefit. These terms are translated from the terms Management, Project Management (Management by Projects) and Management of Projects.

Project management and management of projects are not synonyms. Management of Project includes planning and management of its realization. It is a non-recurring methodological process over a specific project with use of specific project procedures, tools and techniques. Management by Projects, then, is the management of one or more concurrent project, their organization and coordination including specific organizational structure of the company. This term is also used to refer to the scientific field dealing with theory and practice of projects.

\section{Project management methodology}

Project management has not been formed in a moment, but it developed gradually by creating, using and précising the verified approaches and procedures in solution of various project situations. Historical development and different conditions has resulted, globally, in several approaches to solution of the issue of management of projects, which are now represented and advocated by international organizations and their national branches.

In the United States, the organization called Project Management Institute (PMI) came into existence in 1969; it has its representations in more than 185 countries of the world and more than half million members. The company has created an internationally recognised standard providing Project Management Body of Knowledge (PMBOK) (Project Management Institute, 2012). The Czech PMI Chamber was founded as a non-profit civil association in late 2011.

The second biggest organisation dealing with the issue of Project Management is the International Project Management Association (IPMA). Founded in 1965, it currently associates 50 national associations from various places around the world. In our territory, a national company came into existence in February 1990. After formation of the independent Czech Republic, a new association called Společnost pro projektové řízení, o. s. (SPŘ) was admitted to IPMA. The basic publication is the National Standard of Project Management Competences, which is based on the international standard ICB - IPMA Competence Baseline (IPMA, 2012).

The third - in Europe the most widespread - methodology of project management is the PRINCE2 methodology (Projects in Controlled Environment), owned by the UK Office of Government Commerce (OGC). The methodology came into existence in 1989 and was innovated for the last time in 2009. It is required in many countries of Europe and a necessary condition for participation in public contracts. The main source of information is the publication Managing Successful Projects with PRINCE2 (ILX Group Website, 2012).

All the three methodologies and their roofing organizations declare similar activities and objectives in their preambles:

- To explain the basic concepts and principles of project management.

- To show the possibilities and benefits of Project Management.

- To create and maintain technical terminology.

- To describe methods and techniques of project management.

- To issue or participate in issuance of technical literature.

- To specify description of a project manager's profession.

- To certify project managers.

- To present program products for computer support of project management.

- To participate in introduction of project management into practice.

- To organize project management courses.

- To create platform for sharing the knowledge and experience on international level as well.

- To participate in creation of project management legislation.

- To build professional community of project managers.

From the overview it is obvious that the membership in a profession society and managing of any methodology is always an advantage of the manager as a person and benefit for the projects they lead. Selection of specific methodology of project management depends on applicability of the obtained certificate in relevant country and field of activity. Today, certificates can be obtained in this country and examinations can be passed in Czech language. A manager, however, must envisage that nothing is for free - it takes time, effort and money to obtain the certificate.

\section{Building industry management}

Management means leadership, administration or control. Management is a set of experience, knowledge, methods, techniques and tools. 
Process of management deals with coordination of resources (human, financial and material) for the purpose of achieving the specified objective within the given scope, costs, time, quality and satisfaction of the participants. Apart from main tasks, project management has other supporting tasks (administration, documentation, information and communication) and complementary tasks (contract management, quality management, risk management, safety and protection of health at work, environmental protection, statistics).

Position of building industry in national economy is unique. The result of its activity - construction is always an original product, the complexity, time and resource intensity may achieve tremendous values. Construction as such is not the objective of all projects relating to building. Construction is only the means of achieving the objective of the project, which is to satisfy human interests or private, group interest or interests of the whole society. Therefore, development of construction production always precedes the development of other branches. Construction production is considered to be the indicator of future economic growth. Its growth is the harbinger of increased volume of industrial production or services, as applicable, in the period of several years to come.

Building industry, in spite of its development, can never achieve such a degree of mechanisation and automation like the other industrial fields. Its production means shift from place to place, considerable amount of material is transferred, partial negative impact of natural conditions on production process cannot be eliminated.

Final product - structural object or construction as a set of multiple objects - can hardly, and only under simplified preconditions, be compared to other products. Other industrial fields produce multiplepieced series of identical properties for a prolonged period of time and often on multiple places. Production cycle in industrial production takes from several seconds to several days at maximum, and rarely more. Time of realization of a structural object is counted in weeks as a minimum, but more frequently in months and years.

A structural object comes into existence by integrating of hundreds to thousands of types of materials, semi-finished products and products into a building. To process them, many various technologies are used with participation of numerous different professional specialists and application of various tools, machines and equipment. Environment of the construction considerably influences the labour consumption and cost of production. Therefore, even identical building structures or works performed may considerably differ in resource consumption (Nový, 2005).

\section{Management of construction projects}

Construction projects have accompanied humans from time immemorial. Simple building of a primitive dwell in ancient times was, from today's perspective, a simple construction project. In time, humans gathered experience and proved their capabilities by construction project that keep to raise respect and admiration even after centuries, and which would be a tough task to accomplish even in current times of advanced technologies. Any visit to a construction project successfully realized in the past (e.g. the Egyptian pyramids, the Great Wall of China, the Panama Canal) is always a permanent tourist and professional experience.

At the time of centrally planned economy, extraordinary attention was paid to projecting of tangible investments in this country. Details of methodologies and scope of regulations were unprecedented in any other area of preparation of material production. Investments were perceived as limiting factor of the economic development. Financial intensity of investments and long-term character of their preparation resulted in the fact that it was just the investment construction where comprehensive project studies were created. Realization of investments with complicated relationships of a large number of partners and planned procurement of technical and material means could not have been performed without construction projects in a form of "construction organization plan" (COP).

After 1989, more comprehensive information started coming into this country in respect of Project Management as an effective tool for preparation and implementation of projects on both general level and the level of specific methodologies. It came to the light that in construction production, principles of project management are commonly used and that only systematic use of project methods, fast information technologies, new materials and modern machines and equipment can bring improvement and acceleration of projects. The onset of personal computers, specialized programs and electronic communication was the essential development impulse for project planning and management.

\section{Life cycle of construction project}

The result of construction activity - construction work - is always an original product with high degree of complexity, time and resource intensity of which may achieve high values. Objectives of a project are usually specified on three levels cost (price), time (deadlines) and implementation (standards, quality). The same structure is used also for planning, realization and evaluation of construction work. Successful management of all these activities contributes to subdivision of the project interval - from formation of the idea through planning, realization and use up to potential liquidation - into individual phases. These phases are characterised in common activities taking place therein and partial gradual objectives, the meeting of which is the necessary precondition for achieving the final objective of the construction project. With 
regard to time similarity with the human life we refer to life cycle of the project or construction, as applicable (Korytárová and Marková, 2005).

Due to improved effectiveness and quality of works on projects connected with construction, the whole course of the construction cycle is divided into individual phases characterizing specific activities and the resulting documents.

Pre-investment phase is the most important part of the whole construction project. Investor represented by its top management is responsible for it. It defines the objectives, scope, specifications and measurable criteria determining what should be achieved and the method aimed to result in achieving the objectives. Draft project schedule is prepared with use of hierarchic structure of activities. A feasibility study is prepared. The investor decides whether the proposed objectives are feasible under the given conditions and whether the project will continue.

Investment phase is the most laborious and costly part that results in a functional construction. It deals with elaboration of construction plan and management of its realization. The plan is the description of the future optimal course of construction taking all the known conditions and effect into account. Realization is the real course of construction carried out in accordance with the plan with regard to all circumstances, even those unplanned. Documents of this phase are the result of researches, documentation for territorial, building and occupancy procedure including the documentation of real execution of the construction.

Operating phase is the longest part. It starts by handing the construction over into use. Planned and achieved results are evaluated, particularly the cost. Parts of the construction get worn during its operation, therefore is has to be maintained, repaired or renovated, as applicable.

Liquidation phase means termination of the use of construction, its demolition with subsequent recycling or environmentally friendly liquidation of construction materials and construction plot reclamation. Demolition may be replaced by reconstruction with change of the purpose of construction and new occupancy procedure (Nový et al., 2006).

Terminology used in project management is not uniform in this country. One group is represented by nomenclature based on historical development in our territory. The second group is formed by translations or terms taken over from foreign sources (Levy, 2002; Kerzner, 2006).

Construction manager is engaged particularly in the second phase of project, which is subdivided into planning and realization. Individual phases, activities and documents are schematically shown in Fig. 1. The said structure should be perceived as a model, the individual parts of which need not take place chronologically in the specified sequence. Its individual activities may overlap as well. It is not

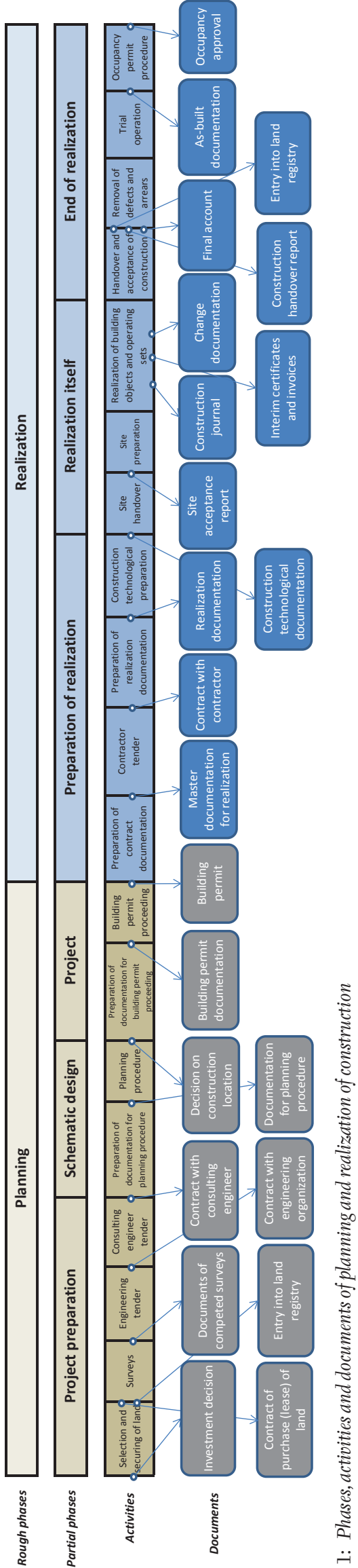


necessary for all the specified items to appear in a particular project; on the other hand, additional specific items for the subject project may be added.

\section{Manager in construction project preparation}

There are numerous factors decisive for success of the project. The objective of the project must be feasible with evaluation of all risks; the project must be well-structured and planned in all respects, implementation of the project must be managed operatively and its progress has to be controlled. All these project activities are provided for by the project management. In simple projects, the management can be represented by a single person all the time; big and complex projects are managed by a project team, the composition of which changes in time depending of professions needed. The project is headed by a person with managing powers and responsibility - the project manager.

In construction projects, the manager's function is physically subdivided into the preparation period (earlier chief project engineer) and the construction realization as such (site managers).

Specification of the cost of realization is a part of the planning phase of projects connected to construction. Acquisition costs of construction form an important part of the project documentation from its very beginning (initial feasibility study) up to its completion (construction account). Realization costs are specified in detail as the draft and documentation are being broken down. The biggest part of the supplier price of construction is represented by costs of construction and installation work including materials and integrated products, the amount of which is most frequently determined by budget. Specifications of individual structures and works, their measures and relevant unit prices are the input data of the budget. Unit price may be determined by calculation from its elements (according to "calculation formula") or by market survey. In both cases, it is the instant price specified as of certain date. Realization of construction part of the project mostly takes place for months to years. Price of gradually completed and invoiced parts of the structure change under the influence of inflation development in the market. It is appropriate to establish the method of its updating in the contracts made. One of the possibilities is to use price indices of construction works or construction objects calculated and published by private business entities or the Czech Statistical Office for specifying the time price.

Budget is one of information source for elaboration of another document - construction schedule. From the budget and structure of its individual items (calculations) it is possible to determine the requirements for human resources (profession), material resources (materials, energies, machines and equipment) and financial (price for performed services and works). Procurement of these resources in time must be optimised from the point of their availability, capacity and

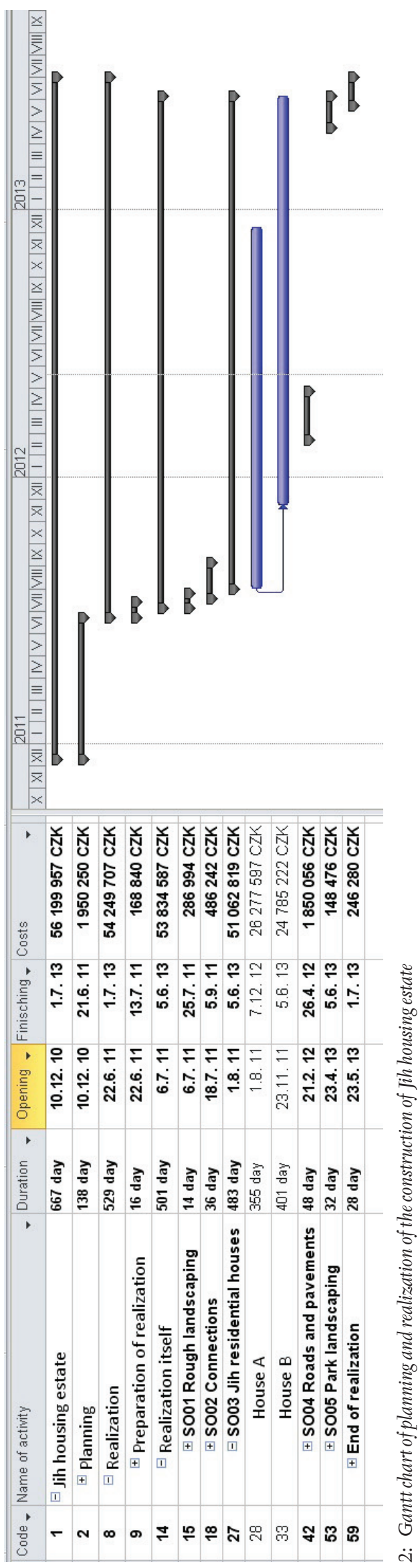


financial coverage. Such elaborated construction plan is commented on and finally approved by the investor, who thereby confirms that the schedule is in accordance with their vision of the time, costs of the project and its specifications.

The method of elaboration of time schedule had been known in this country and used already before the arrival of the methodologies of project management. Formerly, the means necessary for its creation was the calculator, drawing paper, T-square with a ruler and technical pen. Today it is a powerful personal computer with appropriate software and colour printer or plotter. Today's status presents numerous advantages - speed, numerical flawlessness and large amount of calculations, high graphic level, possibility of immediate updating and data sharing practically all over the world. The most frequently used graphic outputs of project planning are the Gantt chart, network chart and frequency bar chart of resources.

The oldest and still used presentation of time course of projects is the Gantt chart (see Fig. 2 and 3). Its author is the American mechanical engineer Henry Laurence Gantt, who started using it for management of project at the beginning of the 20th century already. It is a line chart, where the rectangle in the line represents an individual activity or phase and its length in direction of the time axis corresponds to the period of duration. Various textures or colours can be used to distinguish between individual types of activities. The basic drawing is accompanied by additional graphic symbols showing the sequence of activities, milestones, etc. Texts or numeric values can be included into the chart as well. Next to the graphic part, there is usually a table with nominal description of activities, activity start and end dates and period of duration in the selected time unit. Planned costs, numbers of participants, volumes of basic construction materials can be specified as well. Activities are entered on several hierarchic levels, so individual levels of detail can be displayed separately - structures, objects, technological phases to activities. Fig. 2 shows the time schedule of the construction of Jih housing estate. The phase of realization as such is subdivided into 5 building objects (BOs). The project contains two residential houses A and B. In Fig. 3, the construction of residential houses is further divided into foundation, upper fabric, roof and works of associated construction production (ACP). The time unit used may be the days, weeks, months, quarters and years according to required detail of presentation. Time axis may be placed in real calendar with various length of working shift and working cycle with taking the weekends and days off into account. The entered data may be flexibly adapted. Numerous computer programs exist for saving the necessary data and their display. One of the most globally widespread is Project by Microsoft, which has been used in this model case as well.

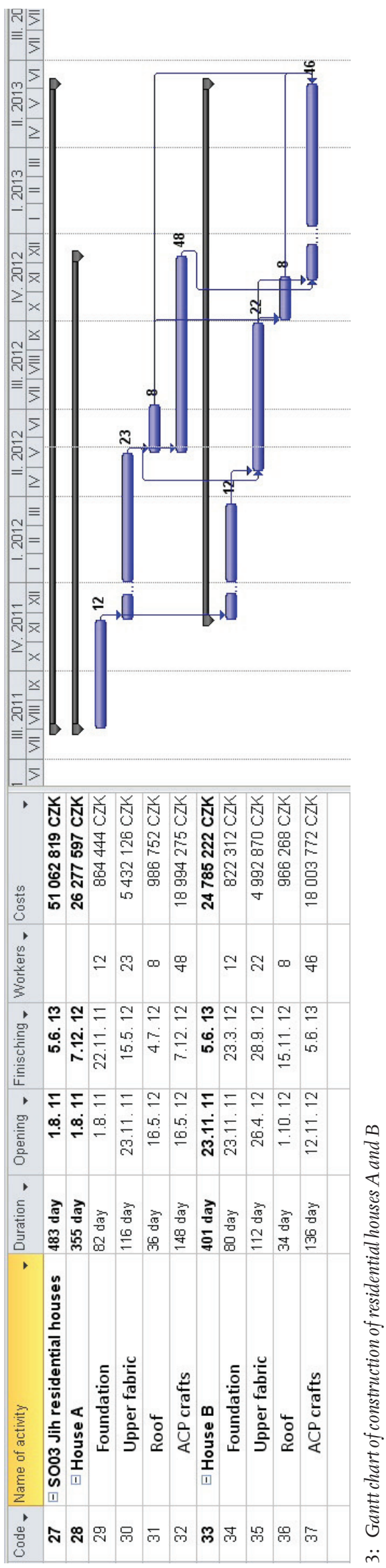


Another graphic output is the "network chart" (see Fig. 4). It is called network chart because it resembles a fishing net with nodes and the threads projected to the neighbouring knots. Two forms of display are use - nodal and line one. In nodal one ("node defined chart") the nodes represent individual planned activities and the lines are relations among the activities. In the line variant (called "edge defined chart") the lines represent individual activities and the nodes are relations among them (bonds). Compilation of the chart is subject to precise rules. Various information about activities and their mutual relations is entered into the chart. The earliest possible and the latest permissible start and end dates of activity are calculated for each activity, and time reserves thereon that may be drawn upon implementation. Basic function of the chart is to find "the critical path" between consequential activities, which determines the total period of duration of the project, and to optimise the whole course of the project. Fig. 4 shows the network chart of construction of the houses A and B. It indicates activities from Fig. 3 with periods of duration and calculated values of the earliest possible and last permissible starts and end dates of individual activities (see the legenda) presented in days. Total reserve shows the period, by which the start of activity may be delayed or by which the activity may be prolonged without prolonging the total period of duration. The "critical path" runs through the activities where the reserve is zero - any delay prolongs the duration of the project or its part.

The third most frequently used graphic output of project planning is the frequency bar chart (Fig. 5). As mentioned before, anything we need to carry out the project is referred to as resource. These are most frequently workforce, finance, material, energies, machines. To get a clear idea, how much of each resource will be needed or present in the given moment on the site, these resources are assigned to activities and subsequently summarized for the selected time sections (days, weeks, months, quarters) or phases (objects) of construction. Frequency bar charts - histograms placed on time axis are compiled from the calculated values. Height of bar is proportional to the size of resource. For instance, the manpower bar chart shows how many workers will be present on site every day. Social amenities on the site must be designed for their maximal number (WC, change rooms, washing facilities) or the maximum may be reduced by appropriate drawing of activity reserves, whereby the cost of construction and operation of the site facilities can be reduced as well. Fig. 5 shows the bar chart of manpower engagement (their numbers) in individual months of construction of houses $A$ and $B$.

Chart making is contained in menus of specialized programs (e.g. MS Project) or a general spreadsheet can be used (MS Excel in Fig. 4 and 5).

Graphical representation of the time course of the project is used as in the pre-investment phase in shaping of the project, as well as in the investment phase for the planning and later in monitoring of the project. In diagrams there can be presented processes for different time periods and different levels of detail. It should be noted that with increasing number of displayed activities and reported numeric or descriptive information clarity and legibility of graphic expression decreases. It is also necessary to distinguish, for whom and for what purpose the graph is intended. It will look completely different graph presenting construction projects for the general public and wide chart showing the coordination of activities such as subcontractors in the construction of the shopping center. Important circumstances it is also a way of presentation. The oral presentation can specify a number of facts or explain. In a written submission is not possible instantaneous contact between author and reader, processing must be clear.

The most universal and the most used graph his Gantt diagram. It is possible to apply it in all phases of the project and for all above mentioned purposes.

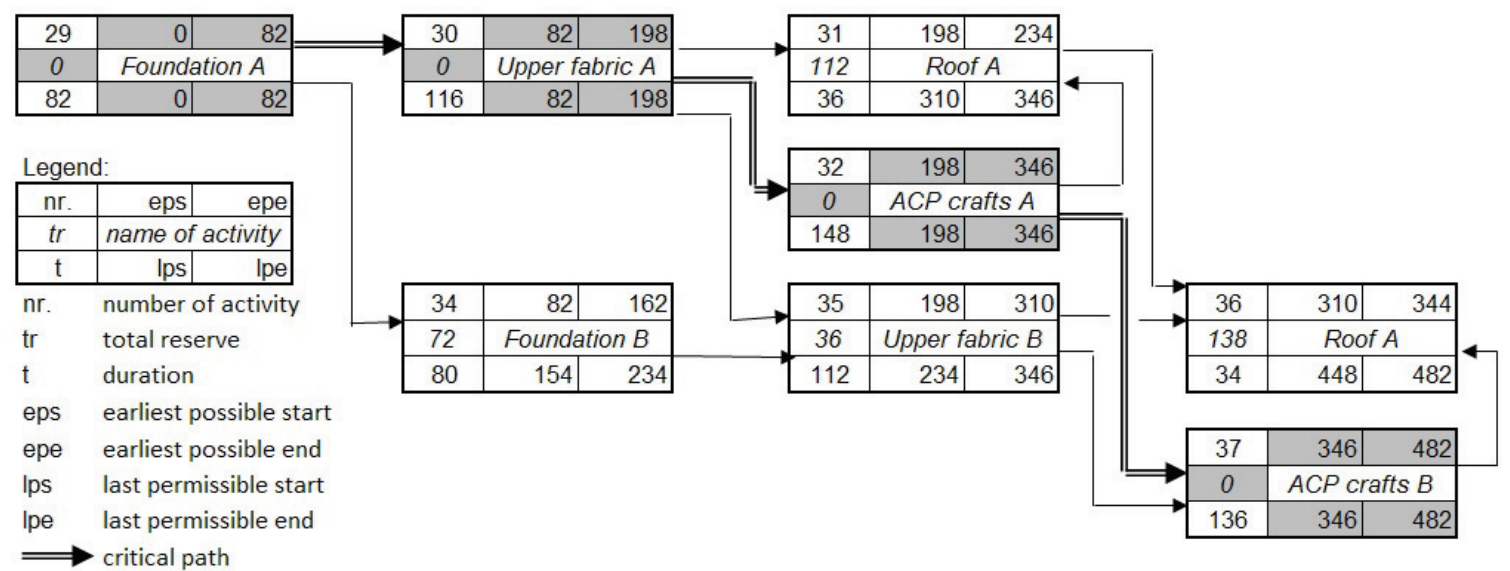

4: Node defined network chart of construction of residential houses A and B 


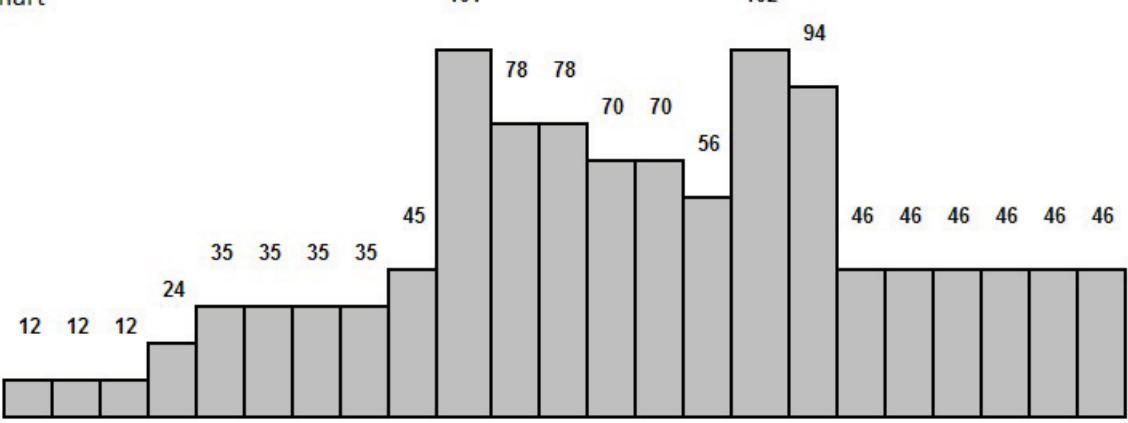

\begin{tabular}{|c|c|c|c|c|c|c|c|c|c|c|c|c|c|c|c|c|c|c|c|c|c|c|c|c|}
\hline \multicolumn{2}{|c|}{ period } & \multirow{2}{*}{ 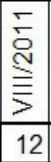 } & \multirow{2}{*}{ 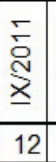 } & \multirow{2}{*}{$\begin{array}{l}\frac{\sigma}{\delta} \\
\stackrel{\odot}{\times} \\
12\end{array}$} & \multirow{2}{*}{ 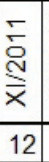 } & \multirow[t]{2}{*}{$\underset{\check{c}}{\grave{\Phi}}$} & \multirow[t]{2}{*}{ 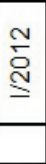 } & \multirow[t]{2}{*}{ 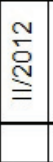 } & \multirow[t]{2}{*}{ 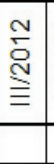 } & \multirow[t]{2}{*}{ 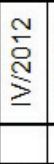 } & \multirow[t]{2}{*}{$\stackrel{\stackrel{N}{\circ}}{>}$} & \multirow[t]{2}{*}{ 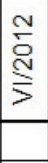 } & \multirow[t]{2}{*}{$\stackrel{\stackrel{N}{\check{C}}}{\stackrel{一}{\supset}}$} & \multirow[t]{2}{*}{ 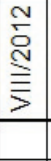 } & \multirow[t]{2}{*}{$\begin{array}{l}\stackrel{\sim}{\check{C}} \\
\stackrel{x}{x}\end{array}$} & \multirow[t]{2}{*}{ 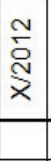 } & \multirow[t]{2}{*}{ 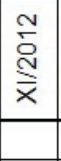 } & \multirow[t]{2}{*}{ 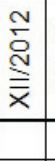 } & \multirow[t]{2}{*}{$\stackrel{m}{\stackrel{m}{\circ}}$} & \multirow[t]{2}{*}{ 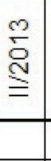 } & \multirow[t]{2}{*}{$\stackrel{\stackrel{m}{\circ}}{\equiv}$} & \multirow[t]{2}{*}{ 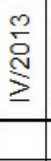 } & \multirow[t]{2}{*}{$\stackrel{m}{\stackrel{m}{\circ}}$} & \multirow[t]{2}{*}{ 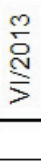 } \\
\hline house A & foundation & & & & & & & & & & & & & & & & & & & & & & & \\
\hline & upper fabric & & & & & 23 & 23 & 23 & 23 & 23 & 23 & & & & & & & & & & & & & \\
\hline & roof & & & & & & & & & & 8 & 8 & 8 & & & & & & & & & & & \\
\hline & ACP crafts & & & & & & & & & & 48 & 48 & 48 & 48 & 48 & 48 & 48 & 48 & & & & & & \\
\hline \multirow[t]{4}{*}{ house B } & foundation & & & & 12 & 12 & 12 & 12 & 12 & & & & & & & & & & & & & & & \\
\hline & upper fabric & & & & & & & & & 22 & 22 & 22 & 22 & 22 & 22 & & & & & & & & & \\
\hline & roof & & & & & & & & & & & & & & & 8 & 8 & & & & & & & \\
\hline & ACP crafts & & & & & & & & & & & & & & & & 46 & 46 & 46 & 46 & 46 & 46 & 46 & 46 \\
\hline total & & 12 & 12 & 12 & 24 & 35 & 35 & 35 & 35 & 45 & 101 & 78 & 78 & 70 & 70 & 56 & 102 & 94 & 46 & 46 & 46 & 46 & 46 & 46 \\
\hline
\end{tabular}

5: Bar chart of manpower engagement in construction of residential houses A and B

Professional software allow after the fulfillment of relevant database quite fast elaboration of complicated but nevertheless well-arranged graphs with sophisticated utilization of idea-graphic tools (form, color, grid). Contrary net graph becomes untransparent for projection of several tens of activities. If it is not possible to arrange its typology without crossing of connections, it is intended only for specialists. It is used in the phase of planning. For assurance of transparency it is possible to divide it into several levels with rising detail and shorter time period. Histogram is mostly used for expression of the time course of one attitude for purposes of the planning of resources. Respecting rules for elaboration it is in all cases schematic and transparent. Described graphs are integral part of the project documentation in al lit phases. They are required by investor at elaboration of the project and it is realized by manager of the management of the preparation and the realization of the project.

The project manager has a great assistant in the state-of-the-art hardware and software tools. They must, however, keep in mind all the time that the program can only process the entered data and many mistakes therein can remain undisclosed for a long time. Everyone should use IT with caution, be aware of the algorithms used and understand the logic of the issued being addressed.

\section{CONCLUSION}

Building industry management is a field of human activity, which comprises numerous partial activities - planning, organizing, human resource management, operating management, controlling, decision making, informing, documenting - focused on preparation and management of construction. A good manager has to manage all these areas. To do this, they need not only professional knowledge obtained in study, but particularly practical experience that can only be obtained by interacting with people. Project management is a proved and globally widespread system of management; being a system of verified skills and procedures, it affects processes connected with construction. Project management is a system of knowledge and skills recognized and required in terms of administrative procedures of European Union, banks and investors. Probability of achieving the objective of the projects within the planned times, costs and quality is increasing. Knowledge of project management belongs to education of construction engineers, increasing their competitiveness in the labour market. 


\section{Acknowledgement}

The article has been prepared with the support of the Ministry of Education, Youth and Sports, Reg. No. CZ.1.07/2.2.00/28.0301 titled "Central European Centre for Creation and Realization of Innovated Technical Economic Study Programs" at the Faculty of Civil Engineering, Brno University of Technology.

\section{REFERENCES}

Project Management Institute [online]. 2012 [cit. 201203-04]. About Us. Available from: <http://www. pmi.org/About-Us.aspx>.

IPMA [online]. 2012 [cit. 2012-03-04]. History. Available from: $<$ http://ipma.ch/about/ $>$.

ILX Group Website: PRINCE2 [online]. 2012 [cit. 2012-03-04]. About Prince2. Available from: $<$ http://www.prince2.com/what-is-prince2-new. asp $>$.

LEVY, SIDNEY, M., 2002: Project management in construction, New York, McGraw-Hill, 427. ISBN 0-07-139587-3.
KERZNER, H., 2006: Project management: a systems approach to planning, scheduling, and controlling, New York, Wiley, 1014. ISBN 0-471-74187-6.

KORYTÁROVÁ, J., MARKOVÁ, L., 2009: Ekonomie a celoživotní cyklus staveb. Stavitel. 2009, 12: pp. 26-27. ISSN 1210-4825.

NOVÝ, M., NOVÁKOVÁ, J., WALDHANS, M., 2006: Životní cyklus stavby v projektovém řízení. In: Cena a životní cyklus stavebního díla. Brno, VUT v Brně, Fakulta stavební, s. 118-124. ISBN 80-2143189-X.

NOVÝ, M., 2005: Osobní příspěvek ke zvyšování konkurenceschopnosti ve stavebnictví, In: Konkurenceschopnost na evropském stavebním trhu. Brno, VUT v Brně, Fakulta stavební, s. 146-151. ISBN 80-214-2836-8.

Ing. Martin Nový, CSc., Ing. Jana Nováková, Ing. Miloš Waldhans, Ústav stavební ekonomiky a řízení, Fakulta stavební, Vysoké učení technické v Brně, Veveří 331/95, 60200 Brno, Česká republika, e-mail: novy.m@fce. vutbr.cz, novakova.j@fce.vutbr.cz, waldhans.m@fce.vutbr.cz 
